\title{
Analysis of Product Differentiation Strategy and its Implications toward Position Advantage on Customer Retailer's Purchase Decision
}

\author{
Dedi Sulistiyo Soegoto \\ Master of Management \\ Universitas Komputer Indonesia \\ Bandung, Indonesia \\ dedi.sulistiyo@email.unikom.ac.id
}

\begin{abstract}
This study aimed to analyze the strategy of product differentiation and its implications on position advantage on customer retailer's purchase decision either partially or simultaneously. The research method used quantitative method with linear regression analysis three variables measured were: product differentiation strategy and advantage position as independent variable and purchase decision as a dependent variable. The object of this research was the customer retailer as the unit of analysis. Technique of Data collection used saturated random sampling with 400 respondents of retailer customers in Bandung. The statistical analysis used Classical Assumption Test and hypothesis

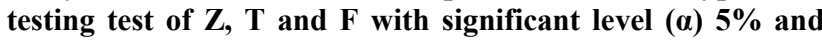
calculated by statistical analysis test. The result indicated significant influence to the product differentiation strategy, position advantage, and purchase decision. The variable of product differentiation strategy and position's advantage influenced the purchase decision either partially or simultaneously.
\end{abstract}

\section{Keywords--- Product Differentiation Strategy, Position Advantage, and Purchase Decision}

\section{INTRODUCTION}

The main challenge in the business world or business is not only derived from the same business competition, but because of government policies or newcomers, business or retailer business is closely related to the economy and economic system. Growth and development of society and the current era of progress, business or business in retailers need to be managed effectively and efficiently in achieving its goals. The starting point in effective management is to determine the expected goals or objectives as well as determine the plan. Entrepreneurs need to make decisions about the planning activities or work programs / strategic plans of business or business in retailers are made based on existing problems in meeting the needs of the community as the business grows. In general, the goal to be achieved in a business or business in the field of retailers is different from other businesses or businesses, depending on the vision and mission of the business or business in the retailer. Every business has a purpose or reason for its existence. In general, businesses or businesses in retailers are more aimed at making a profit. As a system, business or business in the retailer is closely related to the environment. The terminology of the meaning of business or business in the retailer as a system means as a unit consisting of subsystems, such as economic resources, activities and environment that work together to achieve certain goals. Business management becomes increasingly complex as the economic environment develops. Developments in industrial systems and mechanisms have implications for business or business. The alternatives of the opportunities that are still there are many and open to face in achieving its goals. This phenomenon is seen in the city of Bandung which is a tourist destination for tourists who come from the city around Jabar city, in line with the business environment has a strong dependence on economic conditions, industry and interests in other community members. Because of that environment, business decisions are heavily influenced by the interests of parties who come from different backgrounds (economy, social and lifestyle) are different. Basically the business is related to the internal environment as a resource that directly affects business activities. Enterprises are also influenced by the external environment consisting of the main stakeholders of the business or business in the retailers (stakeholders) and the general environment that is indirectly related to the activity or affect the performance of business or business in retailers. Another phenomenon related to retail is now seen in the first curve of 2017 experienced a decline. Statistics show in May 2016 the retail sector grew $11.1 \%$. That shows where the growth of the retail industry from day to day even from month to month does not look satisfactory growth, and decreased, more or less for April only grew $4.1 \%$, but in May fell $3.6 \%$. This is based on the existing retailers in Indonesia, such as minimarket, supermaret, hypermarket, departement store and wholesale. This phenomenon indicates the attractiveness of retail that has not been optimal so as to create a mismatch between consumers of retail business, the business to encapsulate the activities of retail customers are not only able to facilitate the presence of retail stores in an area but the most important factor is how to make a difference, excellence with the best. The linkage of a particular group of individuals or individuals as more demanding, aggressive, and easily dismayed consumers will provide a problem if the form of presentation, appeal and service we provide is perceived as insufficient in this 
regard which should be anticipated in such a way as to minimize it and not created disappointment and the gap between consumers with retail stores are prolonged especially the problem of consumer needs / interests while shopping, and can be resolved properly. What retailers do to customers are basically trying to give the impression of discrimination to consumers, maintaining customers, building an adequate edge. If these things can already be achieved by the retail business, the success of business and victory in the competition will be obtained.

Based on the existing phenomenon, this research is conducted to examine how exactly the company tries to build Strategy differentiation product and, Position Advantage which later can impact on Purchase Decision and of course will give positive impact for company.

Retailing includes all the activities in selling goods or services directly to final consumers for personal, nonbusiness use. A Retailer or retail store is any business enterprise whose sales volume comes primarily from retailing [1].

This study aims to analyze the strategy of product differentiation and its implications on position advantage on costumer retailer's purchase decision either partially or simultaneously.

\section{a). Strategy differentiation product}

Product differentiation occurs when a product offering is perceived by the buyer as different from the competition on any physical or nonphysical product characteristic, including price [2]. The strategy of differentiation requires that the firm creates either a product or provides a service, that is recognized as being unique, thus permitting the firm to command higher than average prices. Because of the loyalty created for a brand, demand is price-inelastic, leading to higher profit margins for the manufacturer [3]. Differentiation: here the company concentration on creating a highly differentiated product line and marketing program so that it comes across as the class leader in the industry. Most customer would prefer to own this brand if its price is not too high [4]. Differentiation product is a strategy that companies use to achieve market power, done by producing that has a different positive identity in the minds of consumers [5]. In the opinion of previous experts that, the three types of product differentiation strategies can be regarded as three different emphases in an overall product differentiation strategy. Firms that adopt differentiation strategies tend to differentiate their products by several means at the same time [6]. Firms may differentiate their products by, for instance, increasing their technological sophistication, increasing their innovative features, offering higher quality standards, improving their image or achieving higher customer service. Moreover, firms may project reputations as socially and environmentally responsive producers [7].

\section{b). Positions Advantage}

The combination of marketing actions used to communication the positioning concept to targeted buyers. A positioning strategy is effort to position the product in the consumers' eyes using price as a cue, the other side former focuses on becoming the most cost-efficient producer of the product [8]. In the opinion of previous experts that functional values relate to the tangible product features satisfying customers' practical needs, symbolic values refer to the intangible values satisfying customers' self-expression needs. Positioning, developing the value proposition, is the process of putting together the value statement that will be communicated to the customer and throughout the organization [9]. Positional advantage is closely linked to the marketing mix and can affect customer satisfaction and impact on customer confidence in a company [10].

\section{c). Purchase Decision}

Buyer decisions can be classified according to the extent to which the buyer is involved in the decision. Purchase Decision: The buyer's decision about which brand to purchase. In the evaluation stage, the customer ranks brands and forms purchase intentions. Generally, the consumer's purchase decision will be to buy the most preferred brand, but two factors can come between the purchase intention and the purchase decision. Post purchase Decision: in the evaluation stage, the consumer forms preferences among the brands in the choices. The consumer may also form an intention to buy the most preferred brand. The stage of the buyer decision process in which consumers take further action after purchase, based on their satisfaction or dissatisfaction. Post purchase action: if the customer is satisfied, she is more likely to purchase the product again. In the opinion of previous experts that demonstrated that the extrinsic product cues of region, price, brand and award do indeed influences how the consumers' decision process works when they are purchasing $[11,12]$. Purchase Decision as proposed, asserted that intention to buy is the buyer's prediction of which company he will select to buy. Intention to buy may be recognized as a reflection of real purchase behavior. The greater the purchase intention is, the greater a consumer's desire is to buy a product $[13,14]$ claimed that marketing endorser's visibility rate can change consumer's personal preference and mind-set and ultimately influence consumer purchase intention [15]. discovered that if a brand provides product features that meets consumer's need, then consumer will form a mental organization in related to the importance of the company toward him or her; subsequently, the consumer will subjectively form his or her relationship with the brand and raise his or her purchase intention accordingly.

\section{METHOD}

Research method used was quantitative method with multiple linear regression analysis. Three variables measured were Strategy Differentiation product, Positions advantage, as independent variable and Purchase decision as dependent variable. The object of this research was retail customer as the unit of analysis. Technique of data collection used saturated random sampling with 96 respondents of retail customers in Bandung. The statistical analysis used Classical Assumption Test and hypothesis testing test of $\mathrm{Z}, \mathrm{T}$ and $\mathrm{F}$ with significant level $(\alpha)$ $5 \%$ and calculated by using statistical analysis test.

\section{a. Multiple Linear Regression Analysis}

By using statistical analysis test., obtained the result of multiple linear regression analysis as follows obtained value a is equal to 231,82 , value of $b 1$ equal to 0,048 , and b2 equal to 0,732 . Thus can be formed multiple linear regression equation as follows: $=231,82+0,048 \mathrm{X} 1+0,732 \mathrm{X} 2{ }^{\wedge} \mathrm{Y}$

The $\mathrm{a}$ and $\mathrm{b}$ values in the above equations can be interpreted as follows:

$\mathrm{a}=231,82$ meaning: if the Strategy of differentiation product and Position Advantage is 0 percent, then Purchase Decision will be worth 231,82 percent.

b1 = 0,048 meaning: if the Strategy of differentiation product increases by one percent while the Position Advantage is constant then Purchase Decision will increase by 0.048 percent. 
$\mathrm{b} 2=0,732$ meaning: if the Position Advantage increases by one percent while the differentiation product strategy is constant then the Purchase Decision will increase by 0.732 percent.

b. Classic assumption test

Furthermore, the analysis of the classical assumption on the figure 1 .

\begin{tabular}{|c|c|c|}
\hline $\begin{array}{c}\text { Best Linier } \\
\text { Unbiased } \\
\text { Estimation Test }\end{array}$ & Criteria 3 & Acceptance \\
\hline $\begin{array}{l}\text { 1. Correlation } \\
\text { serial test: }\end{array}$ & $\begin{array}{l}\mathrm{X}^{2} \text { statistic }<\mathrm{X}^{2} \text { table } \\
\text { where } 2.179<5,99\end{array}$ & $\begin{array}{l}\text { model free from } \\
\text { serial correlation problem }\end{array}$ \\
\hline 2. Normality test & $\begin{array}{l}\text { Jarque-Bera }<\mathrm{X}^{2} \\
\text { table where } 0.231< \\
5,99\end{array}$ & $\begin{array}{l}\text { residual is normally } \\
\text { distributed }\end{array}$ \\
\hline 3. Linearity Test & $\begin{array}{l}\text { Ff-statistic }<\text { f-table } \\
(0.05 ; 2 ; 100)=3.26 \text { so } \\
\text { that } 1.24<3.26\end{array}$ & linear model is acceptable \\
\hline $\begin{array}{l}4 . \\
\text { Heteroscedasticit } \\
\text { y }\end{array}$ & $\begin{array}{l}\text { Obs*R-squared }=5.53 \\
<\text { table chi-square } \\
(5 \%, \text { df })=5.99\end{array}$ & $\begin{array}{l}\text { the model passed the } \\
\text { heteroscedasticity test }\end{array}$ \\
\hline $\begin{array}{l}5 . \\
\text { Multicoliniarity }\end{array}$ & $\begin{array}{l}\text { If } R \text {-squared } 1>R \text { - } \\
\text { squared } 2 \text { then } R- \\
\text { squared } 3=0.416> \\
0.231 ; 0.231\end{array}$ & $\begin{array}{l}\text { the model did not find any } \\
\text { multicoleniarity }\end{array}$ \\
\hline
\end{tabular}

Fig 1. the analysis of the classical assumption. Source: Analysis Data performed by the author on the customer retailer 2018.

\section{RESULTS AND DISCUSSION}

a. Determination Coefficient Analysis

The coefficient of determination (KD) is the square of the correlation coefficient $(\mathrm{R})$ or also known as $\mathrm{R}$-Square. The coefficient of determination serves to find out how much influence Strategy differentiation product and Position advantage against Purchase decision.

From the output of statistical analysis, it is known that the coefficient of determination or $\mathrm{R}$ square is 0,4156 or $41,56 \%$. This shows that the Strategy of Differentiation product and Position advantage simultaneously give influence to Purchase Decision variable equal to $41,56 \%$, so Strategy of differentiation product and Position give big influence to increase Purchase Decision because differentiation product which well managed and position advantage the perceived customer position is expected to improve Purchase Decision. While the rest of 58.44\% is the influence of other variables that are not examined outside the strategy of differentiation product and Position Advantage. and Position Advantage

b. Relationship Strategy Differentiation Product

To test whether Strategy variable of product differentiation and Position advantage have positive or negative relation, then do statistic test of $\mathrm{z}$.

$\mathrm{H} 0: \beta 1=\beta 2=0$,

That is, there is no positive relationship between Strategy differentiation product and Position Advantage on Retail in Bandung.

$\mathrm{H} 1: \beta \mathrm{i} \neq 0$,

That is, there is a positive relationship between the Strategy of differentiation product and Position Advantage on Retail in Bandung.

Significance level $(\alpha)$ : 0,05

Test criteria:

: - reject $\mathrm{HO}$ if value Z-stat $>$ Z-table,

$:$ - accepted $\mathrm{H} 0$ if value $\mathrm{Z}$-stat $<\mathrm{Z}$-table,

From the calculation results obtained $Z$ value of 10.9 . This value will be compared to the $Z$ value of the table. With $\alpha=$ $0,05, \mathrm{Ztable}=\mathrm{Z} \alpha / 2=\mathrm{Z} 0,025=1,96$. From the above values, it is known that the value of $Z$ arithmetic $(10,9)>Z$ table $(1,96)$, so that $\mathrm{HO}$ is rejected and $\mathrm{Ha}$ accepted, $\mathrm{Z}$ value with positive sign showing relationship between customer relationship management and Position advantage is unidirectional, the strategy of differentiation product includes how much Position advantage is available. Value 10.9 shows that assuming variable X1 (strategy of differentiation product) constant means there is a positive relationship between differentiation product strategy (X1) and Position advantage (X2) in retail in Bandung city.

\section{c. Influence Strategy of differentiation product} and Position Advantage on Purchase Decision (Test Statistic t)

Testing Strategy differentiation product Against Purchase Decision

Ho: $\beta 1=0$

The strategy of differentiation product partially has no significant effect on Purchase Decision.

Ha: $\beta 1 \neq 0$

The strategy of differentiation product is partially significant to Purchase Decision.

With the level of significance $\alpha=5 \%$

Based on the processing using statistical analysis test., it can be seen that t-Stat value for Strategy of differentiation product is 0.53 . This value will be compared to the value of $t$ table in the distribution table $\mathrm{t}$. With $\alpha=0.05, \mathrm{df}=\mathrm{n}-\mathrm{k}-1=96-(3-1)=$ 94, for the two-sided test the value of $\mathrm{t}$ table is 1.66. It is known that $\mathrm{t}$-Stat for X1 $(0,53)<\mathrm{t}$-table and is in both t-table value $(-1,66$ and 1,66), hence $\mathrm{Ho}$ is accepted meaning strategy of differentiation product partially has no significant effect to Purchase Decision. This means that if the strategy differentiation product is improved, it does not have a significant effect on increasing Purchase Decision. 
Decision

\section{Testing Position Advantage Against Purchase}

Ho: $\beta 1=0$

Position Advantage partially has no significant effect on Purchase Decision.

Ha: $\beta 1 \neq 0$

Position advantage is partially significant to Purchase Decision. With significance level $\alpha=5 \%$

Criteria: - Reject Ho if t-Stat is bigger than t table, Accept in other things

Based on the results of processing, it can be seen that the value of t-Stat for Position advantage is 8.15 . This value will be compared to the value of $t$ table in the distribution table $t$. With $\alpha=0.05, \mathrm{df}=\mathrm{n}-\mathrm{k}-1=96-(3-1)=94$, for a two-tailed test, the $\mathrm{t}$ table value is 8.15 . It is known that $\mathrm{t}-\mathrm{Stat}$ for $\mathrm{X} 2(8.15)>\mathrm{t}$-table and is outside the two t-table values (-1,66 and 1.66), Ho is rejected as Position Superiority partially significant to Purchase Decision. That is, if the Position advantage is improved, then Purchase Decision will increase in Retail in Bandung.

\section{d. Influence Strategy of differentiation product} and Position Advantage to Purchase Decision (Test Statistic F)

To test whether Strategy variable of differentiation product and Position advantage simultaneously give significant influence to Purchase Decision, then tested the simultaneous hypothesis as follows:

$\mathrm{H} 0: \beta 1=\beta 2=0$,

That is, there is no effect Strategy differentiation

product and Position Advantage on Retail in Bandung.

Ha: $\beta \mathrm{i} \neq 0$,

That is, there is influence of Strategy Differentiation

and Position Advantage Position on Retail in Bandung.

Significance level $(\alpha)$ : 0,05

Test criteria:

- reject $\mathrm{H0}$ if value F-stat > F-table,

- accept Ha if the value F-count < F-table

From the data processing with statistical analysis test., we can know the value of F-stat equal to 33,06 . This value will be compared to the $\mathrm{F}$ table value. With $\alpha=0,05, \mathrm{v}=2$ and $\mathrm{df}=$ 94, it is known that $\mathrm{F}$ table value is 3.09. From the above values, it is known that F-stat (33.06)> F table (3.09), so H0 is accepted and $\mathrm{Ha}$ is rejected, meaning there is significant simultaneous influence from Differentiation product strategy (X1) and Position advantage X2) to Purchase Decision (variable Y), indicating that Strategy of differentiation product and Position advantage simultaneously have significant effect on Purchase Decision. That is, if the Strategy of differentiation product and Position advantage is well managed and enhanced, Purchase Decision will increase as well.

\section{CONCLUSION}

Based on the results of data analysis and discussion that has been done, the authors take the following conclusions: a Strategy differentiation product on Retail in Bandung as a whole is good value. b. Excellence Position on Retail in the city of Bandung good value as a whole. c. Purchase Decision on Retail in Bandung as a whole is good value. 2. There is a positive relationship between differentiation product strategy and position advantage in Retailer Bandung. Application of differentiation product strategy is good able to increase Position advantage, and good Position advantage able to increase the purchase decision 3. Strategy of differentiation product partially significant effect on Purchase Decision. This may be due to the fact that in retail business Strategy of differentiation product influences partially to customer and company, so also product excellence. 4. Position advantage partially significant effect on Purchase Decision. Customers who receive the benefits will feel good they are against company and company products. 5 . There is significant simultaneous influence of differentiation product strategy and Position Advantage to Purchase Decision.

\section{REFERENCES}

[1] Kotler Philip and Kevin Lane Keller, "Marketing Management", 13th Edition, New Jersey: Pearson Prentice Hall. 213,482 (2009)

[2] Cravens, David W., and Nigel F. Piercy., Strategic Marketing, New York: Mc Graw Hill. 94,98, 194 (2009).

[3] Aulakh, P.S., Kotabe, M. and Teegen, H. "Export strategies and performance of firms from emerging economies: evidence form Brazil, Chile and Mexico", Academy of Management Journal, Vol. 43 No. 3, pp. 342-61 (2000).

[4] Bhat, S. \& Reddy, S. K.," Symbolic and functional positioning of brands", The Journal of Consumer Marketing, Vol 15, pp. 32-43 (1998)

[5] Case, Karl. E., and Fair, Ray. C. Principles of Economics. Eighth Edition. New Jersey: Prentice Hall. 355 (2007).

[6] Dirk Michael Boehe and Luciano Barin Cruz. 'Corporate Social Responsibility, Product Differentiation Strategy and Export Performance', Journal of Business Ethics 91:325-346 (2010).

[7] Fombrun, C. and M. Shanley: 1999, 'What's in a Name? Reputation Building and Corporate Strategy', Academy of Management Journal 33(2), 233-258.

[8] Weerawan Marangkun, and Nik Kamariah Nik Mat, 'The Determinants Of Brand Equity In Handicraft SME In Thailand", International Journal of Arts \& Sciences. 4(09):427-442 (2011)

[9] Frederick E, Webster, Jr. Market-Driven Management "Using The New Marketing Concept to Create a Customer-Oriented Company”. New York: John Wiley \& Sons, Inc. 281 (1994).

[10] Soegoto Sulistiyo, Dedi. Pengaruh Kinerja Bauran Pemasaran Jasa Keunggulan Positions Terhadap Kepuasan Penumpang Dan Implikasinya Pada Kepercayaan Penumpang Pesawat Perusahaan Penerbangan Rute Jakarta-Surabaya. Majalah Ilmiah Unikom. Vol.8 No.1 (2011).

[11] Locksin, L., Wade, J. , François d'Hauteville, and Perruti, J.P., "Using simulations from discrete choice experiments to measure consumer sensitivity to brand, region, price, and awards in wine choice", Food Quality and Preference, Vol. 17 No 3-4,pp. 166-178 (2006).

[12] Amir Nasermoadeli1, Kwek Choon Ling1 and Farshad Maghnati Evaluating the Impacts of Customer Experience on Purchase Intention. International Journal of Business and Management; Vol. 8, No. 6; 128-138 (2013). 2013. www.ccsenet.org/ijbm International Journal of Business and Management Vol. 8, No. 6; 128 (2013).

[13] Chi, H. K., Yeh, H. R., and Huang, M. W. The influences of advertising endorser, brand image, brand equity, price promotion on purchase intention: The mediating effect of advertising endorser. The Journal of Global Business Management, 5(1), 224-233 (2009).

[14] Laroche, M. K. C., and Zhou, L. Brand familiarity and confidence as determinants of purchase intention: an empirical test in a multiple brand context. Journal of Business Research, 37, 115-120 (1996).. http://dx.doi.org/10.1016/0148-2963(96)00056-2 
[15] Fournier, S. Consumers and their brands: Developing relationship theory in consumer research. Journal of Consumer Research, 24(4), 343-373. (1998). http://dx.doi.org/10.1086/209515 